\title{
HPLC method development for the simultaneous analysis of amlodipine and valsartan in combined dosage forms and in vitro dissolution studies
}

\author{
Mustafa Çelebier ${ }^{1}, M_{\text {Mstafa Sinan Kaynak }}^{2,3}$, Sacide Altınöz ${ }^{1, *}$, Selma Sahin $^{2}$ \\ ${ }^{1}$ Department of Analytical Chemistry, Faculty of Pharmacy, Hacettepe University, Ankara, Turkey, ${ }^{2}$ Department of \\ Pharmaceutical Technology, Faculty of Pharmacy, Hacettepe University, Ankara, Turkey, ${ }^{3}$ Department of Pharmaceutical \\ Technology, Faculty of Pharmacy, Inönü University, Malatya, Turkey
}

\begin{abstract}
A simple, rapid and reproducible HPLC method was developed for the simultaneous determination of amlodipine and valsartan in their combined dosage forms, and for drug dissolution studies. $\mathrm{AC}_{18}$ column (ODS 2, $10 \mu \mathrm{m}, 200 \times 4.6 \mathrm{~mm}$ ) and a mobile phase of phosphate buffer ( $\mathrm{pH} 3.6,0.01 \mathrm{~mol} \mathrm{~L}^{-1}$ ):acetonitrile: methanol $(46: 44: 10 \mathrm{v} / \mathrm{v} / \mathrm{v})$ mixture were used for separation and quantification. Analyses were run at a flow-rate of $1 \mathrm{~mL} \mathrm{~min}^{-1}$ and at ambient temperature. The injection volume was $20 \mu \mathrm{L}$ and the ultraviolet detector was set at $240 \mathrm{~nm}$. Under these conditions, amlodipine and valsartan were eluted at $7.1 \mathrm{~min}$ and $3.4 \mathrm{~min}$, respectively. Total run time was shorter than $9 \mathrm{~min}$. The developed method was validated according to the literature and found to be linear within the range $0.1-50 \mu \mathrm{g} \mathrm{mL}^{-1}$ for amlodipine, and $0.05-50 \mu \mathrm{g} \mathrm{mL}^{-1}$ for valsartan. The developed method was applied successfully for quality control assay of amlodipine and valsartan in their combination drug product and in vitro dissolution studies.
\end{abstract}

Uniterms: Amlodipine besylate. Valsartan. High Performance Liquid Chromatography. Method Development. Validation. Dissolution Study.

Desenvolveu-se método de HPLC rápido e reprodutível para a determinação simultânea de anlodipino e valsartana em suas formas de associação e para os estudos de dissolução dos fármacos. Utilizaram-se coluna C18 (ODS 2, $10 \mu \mathrm{m}, 200$ x 4,6 mm) e fase móvel tampão fosfato (pH 3,6, 0,01 mol L-1):acetonitrila: metanol para a separação e a quantificação. As análises foram efetuadas com velocidade de fluxo de $1 \mathrm{~mL}$ min $^{-1}$ e à temparatura ambiente $\mathrm{O}$ volume de injeção foi de $20 \mu \mathrm{L}$ e utilizou-se detector de ultravioleta a $240 \mathrm{~nm}$. Sob essas condições, anlodipino e valsartana foram eluídas a 7,1 min e 3,4 min, respectivamente. O tempo total de corrida foi menor que $9 \mathrm{~min}$. O método desenvolvido foi validado de acordo com a literatura e se mostrou linear na faixa de $0,1-50 \mu \mathrm{g} \mathrm{mL}^{-1}$ para anlodipino e de $0,05-50 \mu \mathrm{g} \mathrm{mL} \mathrm{m}^{-1}$ para valsartana. O método desenvolvido foi aplicado com sucesso para ensaios de controle de qualidade de associações de anlodipino e valsartana e nos estudos de dissolução in vitro.

Uniterms: Anlodipino/determinação. Valsartana/determinação. Cromatografia líquida de alta eficiência/ análise quantitativa. Fármacos/dissolução in vitro.

\section{INTRODUCTION}

Amlodipine (as besylate, mesylate or maleate) is a long-acting calcium channel blocker used as an anti-hypertensive agent and in the treatment of angina (Haria, Wagstaff, 1995; Murdoch, Heel, 1991). Akin to other calcium

\footnotetext{
*Correspondence: S. Altınöz. Hacettepe University, Faculty of Pharmacy, Department of Analytical Chemistry. 06100 - Ankara- TURKEY. E-mail: saltinoz@hacettepe.edu.tr
}

channel blockers, amlodipine (AMD) acts by relaxing the smooth muscle in the arterial wall, decreasing peripheral resistance and hence reducing blood pressure. In angina it increases blood flow to the heart muscle. Valsartan (VAL) is an angiotensin II receptor antagonist, acting on the $\mathrm{AT}_{1}$ subtype (Markham, Goa, 1997; Remuzzi et al., 1998). VAL keeps blood vessels from narrowing, which lowers blood pressure and improves blood flow. VAL is used to treat hypertension. It is sometimes given together with other blood pressure medications. It was noted that 
the combination of an angiotensin receptor blocker and a calcium channel blocker constitutes an effective option for patients with hypertension (Boutouvrie et al., 2008; Plosker, Robinson, 2008)

In the literature, several HPLC methods have been described for the determination of AMD in pharmaceutical preparations when used alone (Avadhanulu et al., 1996; Basavaiah et al., 2005; Fang et al., 2007; Kamat, Chaturvedi, 2005; Li et al., 2006; Patki et al., 1994; Shang, Shang, 1996; Ustun, Atay, 2006; Xiao, Wang, 2007) or in combination with other compounds such as atorvastatin, atenolol, benazepril, losartan, ramipril and enarapril maleate (Aravindraju et al., 2006; Barman et al., 2007; Dhorda, Shetkar, 1999; Dongre et al., 2008; Freddy, Chaudhari, 2005; Gowri et al., 2002; Halkar et al., 1998; Luksa et al., 1997; Mohammadi et al., 2007; Rajeswari et al., 2006; Rajkondawar, 2006; Rao et al., 2002; Sankar et al., 1997; Shah et al., 2006; Sivakumar et al., 2007; Zarapkar, Kanyawar, 2002; Zarapkar et al., 1997). HPLC methods for the determination of VAL in pharmaceutical preparations have also been described (Carlucci et al., 2000; Doshi et al., 2008; Han et al., 2007; Jin et al., 2006; Satana et al., 2001; Tatar, Saglik, 2002).

There is an HPLC method described for simultaneous determination of AMD and VAL (Figure 1) in pharmaceutical preparations (Chitlange et al., 2008). In addition, there is another method reported for simultaneous determination of these drugs for liver perfusion studies (Celebier et al., 2008) However, both methods are not developed for dissolution studies while the dissolution profile of AMD and VAL from the combination drug product has not hitherto been reported in the literature. In order to elucidate the dissolution profiles of AMD and VAL, a validated HPLC method is required for simultaneous determination of these drugs in dissolution matrix.

Therefore, the aim of this study was to develop and validate an efficient HPLC method for simultaneous determination of AMD and VAL and to introduce the dissolution profiles of these drugs. Moreover, this new method could also be used for the routine analysis of AMD

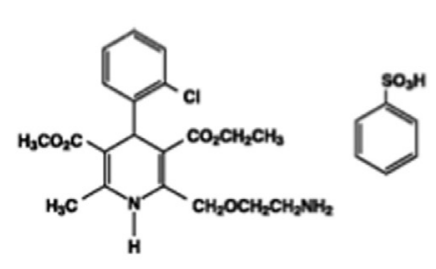

Amlodipine Besylate

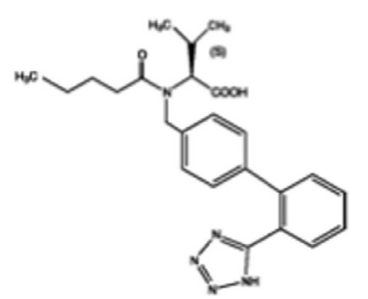

Valsartan
FIGURE 1 - The chemical structures of amlodipine besylate and valsartan. and VAL in pharmaceutical dosage forms, provided it is completely validated and rapid. The newly developed method was totally different both in terms of methodology and aim in comparison to previously reported methods in the literature.

The method was validated according to guidelines (Thompson et al., 2002) and applied for assay of AMD and VAL from their combination tablet dosage form. Also, in vitro dissolution of AMD and VAL containing tablets were performed to validate the suitability of the proposed method.

\section{MATERIAL AND METHODS}

\section{Chemicals}

Standard AMD and VAL were supplied by Refik Saydam National Public Health Agency. Methanol and acetonitrile were of HPLC grade from Merck (Darmstadt, Germany) and all other reagents were analytical grade. Water obtained from the Milli-Q water system (Barnstead, USA) was used for the preparation of buffer and other aqueous solutions. Commercially available tablets $\left(\right.$ Exforge $^{\circledR}$ ) containing $5 \mathrm{mg}$ of AMD (as equal to $6.94 \mathrm{mg}$ of AMD besylate) and $160 \mathrm{mg}$ of VAL were purchased from a local pharmacy.

\section{Solutions}

\section{Standard stock solutions}

Standard stock solutions of AMD and VAL were prepared separately by dissolving $50 \mu \mathrm{g}$ of AMD besylate and $50 \mathrm{mg}$ of VAL in $50 \mathrm{~mL}$ methanol, and stored protected from daylight at $4^{\circ} \mathrm{C}$ until use. These solutions were prepared freshly every week, during method development and application period.

\section{Phosphate buffer solution}

$1.74 \mathrm{~g}$ of $\mathrm{K}_{2} \mathrm{HPO}_{4}$ was dissolved in $1 \mathrm{~L}$ of deionized water and $\mathrm{pH}$ was adjusted to 3.6 with orthophosphoric acid.

\section{Calibration standards}

Calibration standards for AMD (as besylate salt) and VAL $(1.25,2.0,3.0,4.0,10.0,20.0,30.0,40$ and $50.0 \mu \mathrm{g} \mathrm{mL}^{-1}$ ) were daily prepared from standard stock solutions by appropriate dilution processes using mobile phase.

\section{Instrumentation}

The HPLC system consisted of a Waters 2690 Separation Module equipped with a Waters 2996 Photodiode 
Array Detector (Waters, USA). A $\mathrm{C}_{18}$ column (Waters Spherisorp (PSS832514) ODS 2, $10 \mu \mathrm{m}, 200$ x $4.6 \mathrm{~mm}$; USA) was used for separation and quantification. The mobile phase consisted of phosphate buffer $(\mathrm{pH} 3.6$, $\left.0.01 \mathrm{~mol} \mathrm{~L}^{-1}\right)$ : acetonitrile : methanol $(46: 44: 10 \mathrm{v} / \mathrm{v} / \mathrm{v})$ and was filtered through a $0.45 \mu \mathrm{m}$ filter and degassed before use. The injection volume was $20 \mu \mathrm{L}$ and the ultraviolet detector was set at $240 \mathrm{~nm}$. Analyses were run at a flowrate of $1 \mathrm{~mL} \mathrm{~min}^{-1}$ at an ambient temperature $\left(25^{\circ} \mathrm{C}\right)$. The peak areas were integrated automatically by using Empower ${ }^{\mathbb{B}}$ software. Under these conditions, VAL and AMD were eluted at $3.4 \mathrm{~min}$ and $7.1 \mathrm{~min}$, respectively. Total run time was shorter than 9 min.

\section{In vitro dissolution studies}

In vitro dissolution of six tablets containing $\mathrm{AMD}$ and VAL was performed using phosphate buffer $(\mathrm{pH}$ 6.8) as the dissolution media at $50 \mathrm{rpm}$ using an USP Apparatus II. The dissolution study was carried out in a $900 \mathrm{~mL}$ volume of phosphate buffer at $37^{\circ} \mathrm{C}( \pm 0.5)$ using the paddle method. One $\mathrm{mL}$ of sample was withdrawn and replaced with fresh dissolution medium at the time intervals of $0,5,10,15,20$, 30,45 , and 60 minutes. The sample $(250 \mu \mathrm{L})$ was diluted with mobile phase $(750 \mu \mathrm{L})$ and then filtered through a $0.45 \mu \mathrm{m}$ membrane filter. The concentrations of AMD and VAL in samples were determined by the proposed HPLC method.

According to the FDA Guidance (Qui, Xu 2007) no less than $85 \%$ of the active ingredients of the labeled claim should be dissolved within 30 minutes.

\section{Analysis of dosage forms}

Ten tablets were weighed to determine their mean weight, and finely powdered in a mortar. An amount of powdered mass equivalent to one tablet was accurately weighed and transferred to a $100 \mathrm{~mL}$ volumetric flask. A $50 \mathrm{~mL}$ volume of methanol was added then sonicated for $15 \mathrm{~min}$ to ensure complete extraction of the drugs. The flask was then diluted to volume with methanol. An aliquot from this solution was centrifuged at $5000 \mathrm{rpm}$ for $10 \mathrm{~min}$. Clear supernatant was transferred to another flask. Appropriate aliquots from the sample solution were suitably diluted with mobile phase so as to achieve concentrations of $1.25 \mu \mathrm{g} \mathrm{mL}^{-1}$ and $40.0 \mu \mathrm{g} \mathrm{mL}^{-1}$ for AMD and VAL, respectively. Twenty $\mu \mathrm{L}$ of this solution was injected into the HPLC system after filtration through a $0.45 \mu \mathrm{m}$ membrane filter.

\section{Synthetic tablet solutions}

For preparation of the synthetic tablets, common inactive ingredients (microcrystalline cellulose, povidone, talc, magnesium stearate, starch, iron oxide) and standard AMD besylate $(6.94 \mathrm{mg})$ and VAL $(160 \mathrm{mg})$ at amounts equivalent to one tablet were weighed and transferred to a $50 \mathrm{~mL}$ volumetric flask. The same procedure described in Section 2.5 was then applied to prepare the synthetic tablet solutions containing $1.25 \mu \mathrm{g} \mathrm{mL}^{-1}$ of AMD and $40.0 \mu \mathrm{g} \mathrm{mL}^{-1}$ of VAL, respectively. In order to prepare blank tablet solutions, the synthetic tablet solutions were prepared in the absence of AMD and VAL.

\section{RESULTS AND DISCUSSION}

\section{Method optimization}

Due to the relatively apolar properties of AMD and VAL, a reversed phase HPLC system was used to analyze both compounds with a sufficient separation and fine peak shapes within a short analysis time. Therefore, all the experiments were carried out on $\mathrm{a}_{18}$ column (Waters Spherisorp ODS 2, $10 \mu \mathrm{m}, 200 \times 4.6 \mathrm{~mm}$ ) by trying various mobile phase conditions systematically. After the initial experiments, the optimum conditions were found to be the mobile phase of phosphate buffer ( $\left.\mathrm{pH} 3.6,0.01 \mathrm{~mol} \mathrm{~L}^{-1}\right)$ : acetonitrile: methanol $(46: 44: 10 \mathrm{v} / \mathrm{v} / \mathrm{v})$ mixture pumped at $1 \mathrm{~mL} \mathrm{~min}-1$ flow rate and $240 \mathrm{~nm} \mathrm{UV}$ detection wavelength. Under the optimum conditions, VAL and AMD were eluted at $3.4 \mathrm{~min}$ and $7.1 \mathrm{~min}$, respectively.

\section{System suitability}

A suitability test was applied to the chromatograms taken under optimum conditions to check various parameters such as column efficiency (plates), peak tailing, retention factor, and resolution. Suitable resolution $(>2)$ and column efficiency ( $>1500$ for both compounds) were achieved for the analysis method. The peak symmetries for both compounds were $<1.2$, whereas the capacity factors were $>1.5$. The analysis time was shorter than 9 minutes.

\section{Method validation}

The proposed method was validated as to linearity range, sensitivity, repeatability, precision, accuracy, and specificity according to the literature (Ermer, 2001; Ermer, Ploss, 2005; Taverniers et al., 2004a; Taverniers et al., 2004b; Thompson et al., 2006).

\section{Linearity range}

The solutions of AMD and VAL at different con- 
TABLE I - Linearity data of the developed method $(n=6)$

\begin{tabular}{lcc}
\hline & AMD besylate & VAL \\
\hline Regression equation* & $\mathrm{y}=39604 \mathrm{x}+2682$ & $\mathrm{y}=42497 \mathrm{x}+12845$ \\
Standard error of intercept & 308 & 99 \\
Standard error of slope & 758 & 761 \\
Correlation coefficient $(\mathrm{r})$ & 0,9992 & 0,9991 \\
Linearity range $\left(\mu \mathrm{g} \cdot \mathrm{mL}^{-1}\right)$ & $0.1-50$ & $0.05-50$ \\
Number of data points & 8 & 8 \\
LOD $\left(\mu \mathrm{g} \cdot \mathrm{mL}^{-1}\right)$ & 0.05 & 0.02 \\
LOQ $\left(\mu \mathrm{g} \cdot \mathrm{mL}^{-1}\right)$ & 0.1 & 0.05 \\
\hline
\end{tabular}

*where $\mathrm{y}$ is peak area and $\mathrm{x}$ is concentration in $\mu \mathrm{g} \mathrm{mL}-1$

centrations were analyzed. According to the observations, the peak shapes worsened after $50 \mu \mathrm{g} \mathrm{ml}^{-1}$ for both compounds. The graph of the peak area against concentration proved linear up to $50 \mu \mathrm{g} \mathrm{mL}^{-1}$. Therefore, eight different concentrations of AMD and VAL within the linear range were analyzed. This process was repeated six times to calculate the regression equations. The results are given in Table I.

Limit of detection (LOD) and limit of quantitation (LOQ)

The signal-to-noise ratios of 3:1 and 10:1 were taken as LOD and LOQ, respectively (Taverniers et al., 2004a; Taverniers et al., 2004b). The values of LOD and LOQ for both AMD and VAL are given in Table I.

\section{Repeatability}

The repeatability of the developed HPLC method was calculated by 10 consecutive injections made with standard solutions containing $20.00 \mu \mathrm{g} \mathrm{mL}^{-1}$ of AMD and VAL. The results were evaluated by considering retention time and peak area. Neither the peak areas, nor the retention time changed more than $2 \%$, indicating that the method was highly repeatable.

\section{Precision and accuracy}

Three different concentrations of standard AMD and VAL solutions (within the linear range) were analyzed on three consecutive days (inter-day precision) and three times within the same day (intra-day precision). The obtained values for relative standard deviation (RSD) and Bias of intra- and inter-day studies indicated that the precision and accuracy of the method were satisfactory (Taverniers, et al. 2004a; Taverniers, et al. 2004b). The results are summarized in Table II.

\section{Recovery}

To verify the accuracy of the method, recovery experiments were performed. The synthetic tablets and synthetic tablet solutions were analyzed by the developed method. The results were $98.5 \pm 0.8$ and $99.6 \pm 0.6$ (mean $\pm \mathrm{SE}$ where SE is standard error) for AMD and VAL, respectively.

\section{Selectivity}

The chromatograms obtained from standard solutions were identical to those obtained from tablet solutions containing an equivalent concentration of AMD and VAL.

TABLE II - Precision and accuracy of the developed method

\begin{tabular}{lccccccc}
\hline & \multicolumn{3}{c}{ Intra-day } & \multicolumn{3}{c}{ Inter-day } \\
\cline { 2 - 8 } & $\begin{array}{c}\text { Added } \\
\left(\mathrm{mg} \mathrm{mL}^{-1}\right)\end{array}$ & $\begin{array}{c}\text { Found } \\
\left(\mathrm{mg} \mathrm{mL}^{-1}\right)\end{array}$ & $\begin{array}{c}\text { Precision } \\
\text { RSD } \%\end{array}$ & $\begin{array}{c}\text { Accuracy } \\
\text { Bias \% }\end{array}$ & $\begin{array}{c}\text { Found } \\
\left(\mathrm{mg} \mathrm{mL}^{-1}\right)\end{array}$ & $\begin{array}{c}\text { Precision } \\
\text { RSD \% }\end{array}$ & $\begin{array}{c}\text { Accuracy } \\
\text { Bias \% }\end{array}$ \\
\hline Amlodipine bes. & 3 & $2.95 \pm 0.02$ & 1.5 & -3.3 & $2.86 \pm 0.02$ & 2.1 & -4.7 \\
& 20 & $20.38 \pm 0.22$ & 2.6 & 2.8 & $20.83 \pm 0.08$ & 0.9 & 5.4 \\
\hline Valsartan & 40 & $39.28 \pm 0.30$ & 1.9 & -3.2 & $40.24 \pm 0.27$ & 1.6 & -1.5 \\
\hline & 20 & $20.86 \pm 0.03$ & 2.1 & -4.7 & $2.71 \pm 0.03$ & 3.6 & -6.1 \\
& 40 & $39.84 \pm 0.14$ & 2.1 & 4.1 & $20.58 \pm 0.08$ & 0.9 & 4.2 \\
\hline
\end{tabular}

Found: mean \pm standard error ( $\mathrm{n}=6$ ); RSD: Relative standard deviation; Bias: [(Found - Added)/Added] x 100 
The representative chromatograms (Figure 2) show no other peaks in retention time of AMD and VAL and retention times did not change. In addition, when the solution prepared from the blank tablet was injected into the HPLC system, no co-eluting peaks were obtained at the retention time of AMD and VAL.
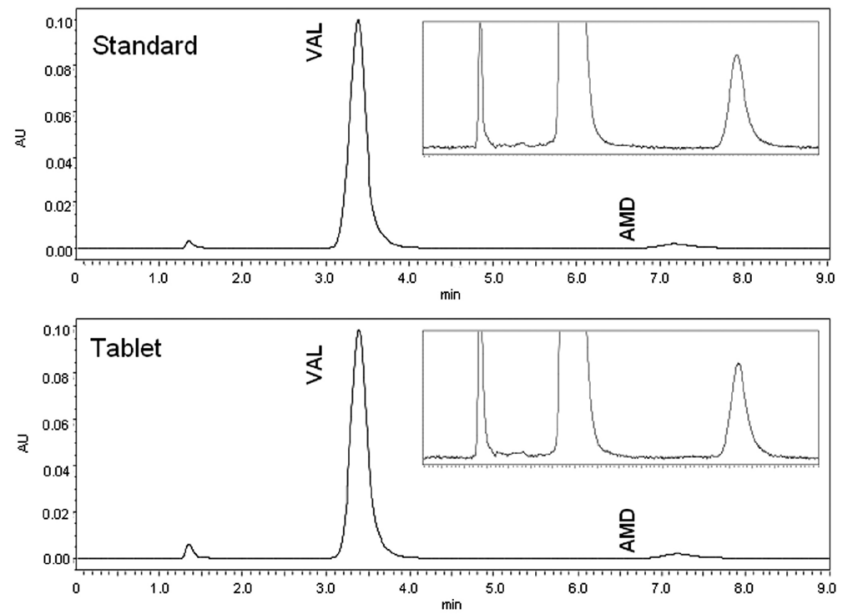

FIGURE 2 - Representative chromatograms obtained from standard and tablet solutions of AMD and VAL (concentrations of AMD and VAL of 1.25 and $40 \mu \mathrm{g} \mathrm{mL}^{-1}$, respectively) Conditions: Phosphate buffer ( $\mathrm{pH} 3.6,0.01 \mathrm{M})$ :acetonitrile:methanol $(46: 44: 10 \mathrm{v} / \mathrm{v} / \mathrm{v}), 1 \mathrm{~mL} \mathrm{\textrm {min } ^ { - 1 }}$ flow rate, $240 \mathrm{~nm}$ UV detection.

Based on these results, the proposed methods can be considered selective.

\section{Tablet analysis results}

The assay results of AMD and VAL in tablet dosage form were comparable with the label value claimed ( $5 \mathrm{mg}$ AMD and $160 \mathrm{mg}$ VAL (Exforge ${ }^{\circledR}$ ). The results presented in Table III indicate the suitability of the method for routine analysis of AMD and VAL from their combination drug products.

TABLE III - Assay of AMD and VAL from its tablet dosage form

\begin{tabular}{ccc}
\hline $\begin{array}{c}\text { Tablet } \\
\text { Solutions }\end{array}$ & Exforge $^{\circledR}$ Tablets (160 mg VAL and 5 mg AMD) \\
\cline { 2 - 3 } & VAL & AMD \\
\hline 1 & 151.93 & 4.74 \\
2 & 156.71 & 4.81 \\
3 & 160.34 & 5.07 \\
4 & 152.47 & 4.74 \\
5 & 152.32 & 4.74 \\
6 & 153.58 & 4.80 \\
Mean \pm SE & $154.56 \pm 1.35$ & $4.82 \pm 0.05$ \\
RSD & 2.15 & 2.61 \\
Bias & 3.40 & 3.64 \\
\hline
\end{tabular}

In vitro dissolution studies

The average percentage drugs released within 60 min as detected by the proposed HPLC method after in vitro dissolution of tablets containing combination drug product are depicted in Figure 3. VAL was completely released within $10 \mathrm{~min}$, whereas $85 \%$ of AMD was released within $15 \mathrm{~min}$. The dissolution pattern complies with the FDA Guidance (Qui and Xu 2007) standards, indicating suitability of the proposed method for the dissolution study of the two drugs.

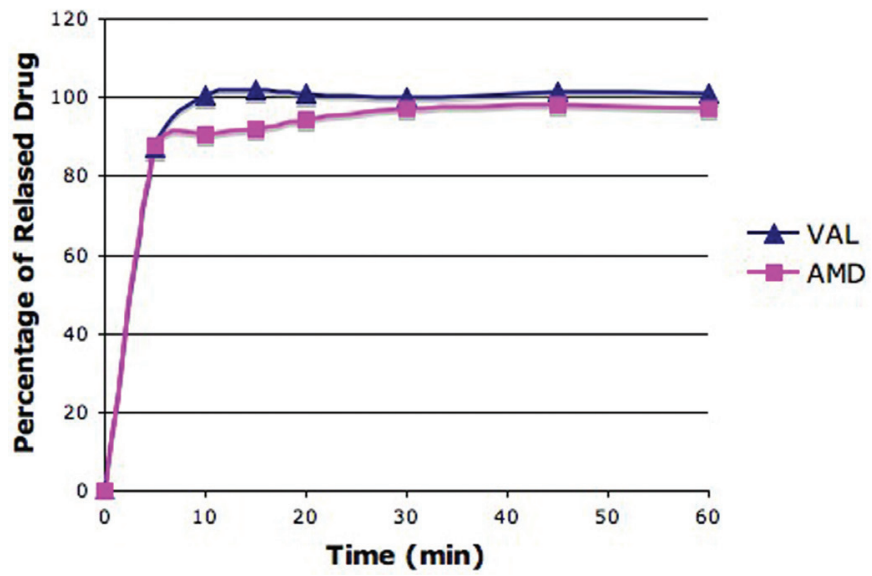

FIGURE 3 - In vitro dissolution profiles of AMD and VAL.

\section{CONCLUSION}

It is a well known that validation procedure is an integral part of the analytical method development. Therefore, the developed method was validated according to the guidelines. Based on the results, it can be concluded that there is no other co-eluting peak with the main peaks and that the method is specific for estimation of AMD and VAL. The proposed method has linear response in the stated range and is accurate and precise. To our knowledge, the developed HPLC method is the first reported method for simultaneous determination of AMD and VAL from their combination drug product. Taken together, these results clearly showed that this method can be used for assay of AMD and VAL in their combination drug product. The developed method can also be conveniently adopted for dissolution testing of tablets containing AMD and VAL.

\section{REFERENCES}

A R AVIN DRA JU, S .; MUR A L IDHARAN, S .; MEYYANATHAN, S.N.; SURESH, B. A validated RPHPLC method for simultaneous estimation of losartan potassium and amlodipine in pharmaceutical formulation. Anal. Chem. (Rajkot, India), v.3, p.66-70, 2006. 
AVADHANULU, A.B.; SRINIVAS, J.S.; ANJANEYULU, Y. Reverse phase HPLC determination of Amlodipine besylate in drug and its pharmaceutical dosage forms. Indian Drugs, v.33, p.36-40,1996.

BARMAN, R.K.; ISLAM, M.A.U.; AHMED, M.; WAHED, M.I.I.; ISLAM, R.; KHAN, A.; HOSSAIN, M.B.; RAHMAN, B.M. Simultaneous high-performance liquid chromatographic determination of atenolol and amlodipine in pharmaceutical-dosage form. Pak. J. Pharm. Sci., v.20, p.274-279, 2007.

BASAVAIAH, K.; CHANDRASHEKAR, U.; NAGEGOWDA, P. Spectrophotometric and high performance liquid chromatographic determination of amlodipine besylate in pharmaceuticals. Sci. Asia, v.31, p.13-21, 2005.

BOUTOUVRIE, P.; LAURENT, S.; ACHOUBA, A. Effect of a fixed dose combination amlodipine/valsartan on central aortic blood pressure in uncontrolled essential hypertension with amlodipine 5mg: The EXPLOR study. J. Hypertens., v.26, p.S170-S170,2008.

CARLUCCI, G.; DI CARLO, V.; MAZZEO, P. Simultaneous determination of valsartan and hydrochlorothiazide in tablets by high-performance liquid chromatography. Anal. Lett., v.33, p.2491-2500, 2000.

CELEBIER, M.; KAYNAK, M.S.; ALTINOZ, S.; SAHIN, S. Validated HPLC method development: the simultaneous analysis of amlodipine and valsartan in samples for liver perfusion studies. Hacettepe University J Faculty of Pharmacy, v.28, p.15-30, 2008.

CHITLANGE, S.S.; BAGRI, K.; SAKARKAR D.M. Stability indicating RP- HPLC method for simultaneous estimation of valsartan and amlodipine in capsule formulation. Asian J. Res. Chem., v.1, p.15-18, 2008.

DHORDA, U.J.; SHETKAR, N.B. Reversed-phase highperformance liquid chromatographic determination of Ramipril and Amlodipine in tablets. Indian Drugs, v.36, p.638-641,1999.

DONGRE, V.G.; SHAH, S.B.; KARMUSE, P.P.; PHADKE, M.; JADHAV, V.K. Simultaneous determination of metoprolol succinate and amlodipine besylate in pharmaceutical dosage form by HPLC. J. Pharmaceut. Biomed., v.46, p.583-586, 2008.
DOSHI, A.S.; BHAGWAN, S.S.; MEHTA, T.N.; GUPTA, V.K.; SUBAAIAH, G. Determination of nebivolol and valsartan in a fixed-dose combination by liquid chromatography. $J$. AOAC Int., v.91, p.292-298,2008.

ERMER, J. Validation in pharmaceutical analysis. Part I: An integrated approach. J. Pharm. Biomed. Anal., v.24, p.755767,2001 .

ERMER, J.; PLOSS, H.J. Validation in pharmaceutical analysis - Part II: central importance of precision to establish acceptance criteria and for verifying and improving the quality of analytical data. J. Pharm. Biomed. Anal., v.37, p.859-870, 2005.

FANG, S-G.;YU, J.; JIANG. Z.; ZHAO, R-W.; YE, Q. Comparison of dissolution of amlodipine besylate tablets from 3 manufactures. J. Chin. Integr. Med., v.24, p.326328,2007 .

FREDDY, H.; CHAUDHARI, V. Simultaneous determination of atorvastatin calcium and amlodipine besylate from pharmaceutical formulation by reversed phase high performance liquid chromatography. Asian J. Chem., v.17, p.2502-2508, 2005.

GOWRI, N.; VAIDHYALINGAM, V.; SHANTHA, A. Simultaneous estimation of amlodipine and benazepril from tablets by RP-HPLC. Indian Drugs, v.39, p.532-535, 2002.

HALKAR, U.P.; BHANDARI, N.P.; RANE, S.H. High performance liquid chromatographic simultaneous determination of amlodipine and enalapril maleate, from pharmaceutical preparation. Indian Drugs, v.35, p.168169,1998 .

HAN, J.; MA, B.; LI, J. Preparation and content determination of valsartan dispersible tablets. Shizhen Guoyi Guoyao, v.18, p.145-146,2007.

HARIA, M.; WAGSTAFF, A.J. Amlodipine - a reappraisal of its pharmacological properties and therapeutic use in cardiovascular-disease. Drugs, v.50, p.560-586, 1995.

JIN, X.; PAN, J.; WANG, B.; Determination of in vitro dissolution of valsartan dispersible tablets with HPLC. Yiyao Daobao, v.25, p.473-474, 2006.

KAMAT, K.; CHATURVEDI, S.C. Stability indicating assay method for amlodipine tablets. Indian J. Pharm. Sci., v.67, p.236-239, 2005. 
LI, C.; YAN, X.; SHAN, W. HPLC determination of amlodipine besylate tablets. Yaowu Fenxi Zazhi, v.26, p.1878-1879, 2006.

LUKSA, J.; JOSIC, D.; PODOBNIK, B.; FURLAN, B.; KREMSER, M. Semi-preparative chromatographic purification of the enantiomers S-(-)-amlodipine and R-(+)amlodipine. J. Chromatog., B, v.693, p.367-375, 1997.

MARKHAM, A.; GOA, K.L. Valsartan - a review of its pharmacology and therapeutic use in essential hypertension. Drugs, v.54, p.299-311, 1997.

MOHAMMADI, A., REZANOUR, N., ANSARI, D.M.; GHORBANI B.F.; HASHEM, M.; WALKER, R.B. A stability-indicating high performance liquid chromatographic (HPLC) assay for the simultaneous determination of atorvastatin and amlodipine in commercial tablets. J. Chromatog. B., v.846, p.215-221, 2007.

MURDOCH, D.; HEEL, R.C. Amlodipine - a review of its pharmacodynamic and pharmacokinetic properties, and therapeutic use in cardiovascular-disease. Drugs, v.41, p.478-505, 1991.

PATKI, R.V.; TAMHANKAR, C.P.; TIPNIS, H.P. Simple and rapid high-performance liquid chromatographic estimation of amlodipine in pharmaceutical dosage [forms]. Indian Drugs, v.31, p.560-561, 1994.

PLOSKER, G.L.; ROBINSON, D.M. Amlodipine/Valsartan - Fixed-dose combination in hypertension. Drugs, v.68, p.373-381, 2008.

QUI, G-C.; XU X-W. Determination of clarithromycin in clarithromycin dispersible tables by HPLC. Xiandai Shipin Yu Yaopin Zazhi, v.17, p.55-56, 2007.

RAJESWARI, K.R.; SANKAR, G.G.; RAO, A.L.; SESHAGIRIRAO, J.V.L.N. RP-HPLC method for the simultaneous determination of atorvastatin and amlodipine in tablet dosage form. Indian J. Pharm. Sci., v.68, p.275$277,2006$.

RAJKONDAWAR, V.V. Simultaneous determination of atorvastatin and amlodipine by reverse phase high performance liquid chromatography. Asian J. Chem., v.18, p.3227-3229, 2006.
RAO, J.R.; KADAM, S.S.; MAHADIK, K.R. Reverse phase high performance liquid chromatographic determination of amlodipine and benazepril HCL in tablets. Indian Drugs, v.39, p.378-381,2002.

REMUZZI, A.; PERICO, N.; REMUZZI, G. Pharmacological and clinical profile of valsartan. Drugs Today, v.34, p.973986,1998 .

SANKAR, S.R.; NANJAN, M.J.; VASUDEVAN, M.; SHAAT, N.; SURESH, B. Simultaneous estimation of atenolol and amlodipine in formulations by reversed phase - HPLC. Indian J. Pharm. Sci., v.59, p.171-173,1997.

SATANA, E.; ALTINAY, S.; GOGER, N.G.; OZKAN, S.A.; SENTURK Z. Simultaneous determination of valsartan and hydrochlorothiazide in tablets by first-derivative ultraviolet spectrophotometry and LC. J. Pharm. Biomed. Anal., v.25, p.1009-1013, 2001.

SHAH, D.A.; BHATT, K.K.; SHANKAR, M.B.; MEHTA, R.S.; GANDHI, T.R.; BALDANIA, S.L. RP-HPLC determination of atorvastatin calcium and amlodipine besylate combination in tablets. Indian J. Pharm. Sci., v.68, p.796-799, 2006.

SHANG, F.; SHANG, K. Determination of amlodipine in tablets by HPLC. Zhongguo Yiyao Gongye Zazhi, v.27, p.411-413, 1996.

SIVAKUMAR, T.; MANAVALAN, R.; MURALIDHARAN, C.; VALLIAPPAN, K. An improved HPLC method with the aid of a chemometric protocol: simultaneous analysis of amlodipine and atorvastatin in pharmaceutical formulations. J. Sep. Sci., v.30, p.3143-3153, 2007.

TATAR, S.; SAGLIK, S. Comparison of UV- and second derivative-spectrophotometric and LC methods for the determination of valsartan in pharmaceutical formulation. J. Pharm. Biomed. Anal., v.30, p.371-375, 2002.

TAVERNIERS, I.; DE LOOSE, M.; VAN BOCKSTAELE, E. Trends in quality in the analytical laboratory. II. Analytical method validation and quality assurance. Trac-Trend Anal. Chem., v.23, p.535-552, 2004a.

TAVERNIERS, I.; VAN BOCKSTAELE, E.; DE LOOSE, M. Trends in quality in the analytical laboratory. I. Traceability and measurement uncertainty of analytical results. TracTrend Anal. Chem., v.23, p.480-490, 2004 b. 
THOMPSON, M.; ELLISON, S.L.R.; WOOD, R. Harmonized guidelines for single-laboratory validation of methods of analysis - (IUPAC technical report). Pure Appl. Chem., v.74, p.835-855, 2002.

THOMPSON, M.; ELLISON, S.L.R.; WOOD, R. The International Harmonized Protocol for the proficiency testing of analytical chemistry laboratories (IUPAC technical report). Pure Appl. Chem., v.78, p.145-196, 2006.

USTUN, F.G.; ATAY, O. Quantitative determination of amlodipine containing pharmaceuticals by IR spectroscopy and HPLC methods. J. Pharm. Istanbul Univ., v.38, p.37-46, 2006.

XIAO, H.; WANG, Y. Study on preparation and quality standard of amlodipine besylate tablets. Zhongguo Yaoye, v.16, p.30-32, 2007.
ZARAPKAR, S.S.; KANYAWAR, N.S. Simultaneous estimation of Amlodipine and Losartan Potassium in pharmaceutical dosage by reverse phase high performance liquid chromatography. Indian Drugs, v.39, p.338341,2002 .

ZARAPKAR, S.S.; KOLTE, S.S.; RANE, S.H. Highperformance liquid chromatographic determination of amlodipine and atenolol, simultaneously, from pharmaceutical preparations. Indian Drugs, v.34, p.350353,1997 .

Received for publication on $12^{\text {th }}$ November 2009. Accepted for publication on $01^{\text {st }}$ June 2010. 